\title{
Partisipasi Masyarakat dalam Program Kampung KB di Masa Pandemi (Studi Kasus Desa Sumberkarang Kecamatan Dlanggu Kabupaten Mojokerto)
}

\section{Community Participation in the Family Planning Village Program during the Pandemic Period (Case Study of Sumberkarang Village, Dlanggu District, Mojokerto Regency)}

\author{
Rizky Sintiah Putri ${ }^{1}$ \\ ${ }^{1}$ Mahasiswa S1 Sosiologi FISH Universitas Negeri Surabaya, Surabaya, Indonesia, \\ Email: rizkysintiahputri@gmail.com
}

\begin{abstract}
A R T I C L E I N F O
\section{How to Cite:}

Putri, R. S. (2021). Partisipasi

Masyarakat dalam Program

Kampung KB di Masa

Pandemi (Studi Kasus Desa

Sumberkarang Kecamatan

Dlanggu Kabupaten

Mojokerto). Hasanuddin

Journal of Sociology (HJS),

3(1), 59-75.

Keywords:

Participation, KB Village,

Covid-19

Kata Kunci :

Partisipasi, Kampung KB,

Covid-19

* Corresponding author. Telp.: -

E-mail address: rizkysintiahputri@gmail.com
\end{abstract}

\begin{abstract}
A B S T RA C T
Sumberkarang Village is a pilot KB Village in East Java. In 2019 Sumberkarang Village won 1st place in the KB Village in East Java in the cross-sector category. Background Sumberkarang Village was appointed as the KB Kampung because of low MKJP, low CPR, high Unmet Need, low male family planning, inadequate facilities and infrastructure. Since it was declared as Kampung KB, community participation in the Kampung KB Program has continued to increase. In 2020, activities at the Sumberkarang Village Family Planning Village will be limited due to the Covid-19 pandemic. This study aims to identify community participation in the Sumberkarang Village Family Planning Village Program during the pandemic. This study used a qualitative approach using two types of data collection techniques, namely primary data and secondary data. Data obtained from observations and interviews, as well as journals related to community participation in the Kampung KB Program. The results of this study indicate that community participation in the Kampung KB Program during the pandemic has decreased. This is because of public concern about the spread of Covid-19. The activities of the Kampung KB Program during the pandemic were very limited in an effort to prevent the spread of Covid19. The technical implementation of Kampung KB activities during the pandemic is by applying health protocols and PHBS habituation. The activities are carried out in turns or in turns to avoid crowds of residents.
\end{abstract}

\section{ABSTRAK}

Desa Sumberkarang merupakan Kampung KB Percontohan se Jawa Timur. Pada tahun 2019 Desa Sumberkarang menjadi juara 1 Kampung KB se Jawa Timur kategori lintas sektor. Latar belakang Desa Sumberkarang ditunjuk 
menjadi Kampung KB karena MKJP rendah, CPR rendah, Unmet Need tinggi, KB pria rendah, sarana dan prasarana tidak memadai. Sejak dicanangkan sebagai Kampung KB, partisipasi masyarakat dalam Program Kampung KB terus meningkat. Pada tahun 2020, kegiatan pada Kampung KB Desa Sumberkarang dibatasi karena pandemi Covid-19. Penelitian ini bertujuan untuk mengidentifikasi partisipasi masyarakat dalam Program kampung KB Desa Sumberkarang di masa pandemi. Penelitian ini menggunakan pendekatan kualitatif dengan menggunakan dua jenis teknik pengumpulan data yaitu data primer dan data sekunder. Data diperoleh dari observasi dan wawancara, serta jurnal terkait dengan partisipasi masyarakat dalam Program Kampung KB. Hasil penelitian ini yaitu partisipasi masyarakat dalam Program Kampung KB di masa pandemi mengalami penurunan. Hal ini karena kekhawatiran masyarakat terhadap penyebaran Covid-19. Kegiatan Program Kampung KB di masa pandemi sangat dibatasi sebagai upaya mencegah penyebaran Covid-19. Teknis pelaksanaan kegiatan Kampung KB di masa pandemi dengan menerapkan protokol kesehatan dan pembiasaan PHBS. Pelaksanaan kegiatan dilakukan secara bergilir atau bergantian untuk menghindari kerumunan warga.

\section{PENDAHULUAN}

Berdasarkan Badan Pusat Statistika (BPS, 2020) jumlah penduduk Provinsi Jawa Timur mencapai 39.886.288 jiwa. Data tersebut menunjukkan kepadatan penduduk di Jawa Timur. Badan Kependudukan dan Keluarga Berencana Nasional (BKKBN) merupakan lembaga pemerintahan yang dibentuk untuk mengendalikan laju pertumbuhan penduduk (Rahman, 2019). BKKBN juga berkontribusi dalam Agenda Prioritas Pembangunan terutama meningkatkan kualitas hidup masyarakat. Pembangunan yang dilakukan dimulai dari unit terkecil dari masyarakat yaitu keluarga. Kegiatan prioritas BKKBN yaitu meningkatkan kesehatan ibu dan anak, KB dan kesehatan reproduksi. Pelaksanaan Program KB dimulai pada tahun 1970-an yang bertujuan untuk mengendalikan pertumbuhan jumlah penduduk. Upaya pemerintah dalam mencapai keberhasilan Program KB dengan mengalokasikan anggaran yang jumlah anggarannya semakin meningkat setiap tahunnya (Welianto, 2020). Pada tahun 2017, BKKBN membuat program penggerak KB yaitu dengan dibentuknya Kampung KB.

Kampung KB merupakan salah satu inovasi strategis dalam meningkatkan kesejahteraan masyarakat. Kampung KB bertujuan melaksanakan delapan fungsi keluarga dan sebagai wadah pelaksanaan Program KKBPK (BKKBN, 2018). Salah satu tujuan Kampung KB melalui Program Bangga Kencana adalah pembangunan keluarga untuk meningkatkan kualitas hidup (Kanalsatu.com, 2019). Kampung KB memiliki peran besar dalam mengatasi masalah kepadatan penduduk. Dibentuknya Program Kampung KB merupakan salah satu langkah pemerintah dalam mengatasi masalah kependudukan. Kepadatam penduduk yang tidak diimbangi dengan kualitas sosial-ekonomi mengakibatkan ketimpangan di masyarakat. Pada tahun 2019 jumlah keluarga pra sejahtera di Indonesia 
mencapai 57.600.000 keluarga. Data tersebut menunjukkan bahwa rendahnya kualitas ketahanan keluarga di Indonesia. Keluarga merupakan aspek terkecil dari masyarakat. Pembangunan keluarga sangat penting untuk meningkatkan ketahanan dan kesejahteraan keluarga.

Berdasarkan data Badan Kependudukan dan Keluarga Berencana Nasional (BKKBN) pada tanggal 23 Juli 2019 ada sebanyak 14.536 kampung KB yang telah dibangun di Indonesia sampai pada tanggal 22 Juli 2019. Sejak awal dicanangkan oleh presiden Joko Widodo pada 14 Januari 2016 di Kabupaten Cirebon, Jawa Barat. Pada tahun 2017 merupakan awal mula diperkenalkan Kampung KB dari Kepala Desa dan Petugas Keluarga Berencana (PKB) serta Pengelola program KB lain yaitu Petugas Pembantu Keluarga Berencana Desa (PPKB). Di desa Cinangsi ini, Kampung KB desa pertama yang dibentuk pada tingkat Kecamatan (Kanalsatu.com, 2019). Kampung KB pertama dibentuk pada tingkat Kecamatan yang memiliki dua jenis sasaran pokok KB yaitu sasaran langsung dan tidak langsung. Sasaran Kampung KB secara langsung meliputi masyarakat, keluarga, Pasangan Usia Subur (PUS), balita, remaja, serta lansia. Adapun sasaran tidak langsung meliputi tokoh masyarakat, organisasi masyarakat, petugas lapangan dan provider. Sasaran ini berdasarkan tujuan dibentuknya Kampung KB sesuai dengan arahan Presiden RI terutama yang dapat dirasakan langsung oleh masyarakat di wilayah miskin, tertinggal, terpencil, dan padat penduduk. Tujuan dibentuknya Kampung KB secara umum yaitu meningkatkan kualitas hidup masyarakat, serta pembangunan sektor lainnya yang terkait dalam rangka mewujudkan keluarga kecil berkualitas. Secara khusus, Kampung KB ini dibentuk untuk meningkatkan peran serta Pemerintah, Lembaga Non Pemerintah dan Swasta dalam memfasilitasi, mendampingi, dan membina masyarakat dalam menyelenggarakan Program Bangga Kencana. Di samping itu, Kampung KB bertujuan meningkatkan kesadaran masyarakat tentang pembangunan berwawasan pendidikan.

Kampung KB tidak hanya berperan dalam pengendalian penduduk, melainkan meningkatkan ketahanan dan kesejahteraan keluarga. Status kesejahteraan dapat diukur dengan proporsi pengeluaran rumah tangga. Pada tahun 2019, BKKBN meluncurkan program baru yaitu program Bangga Kencana. Program Bangga Kencana merupakan program pemerintah yang tidak hanya fokus pada masalah kependudukan dan KB, melainkan lebih fokus pada pembangunan keluarga. Oleh karena itu, sasaran kegiatan Program Kampung KB dari yang terkecil yaitu keluarga. Program ini bertujuan untuk membangun keluarga kecil berkualitas. Kegiatan Program Kampung KB yaitu untuk memaksimalkan penerapan delapan fungsi keluarga. Delapan fungsi keluarga yaitu fungsi agama, kasih sayang, perlindungan, sosial budaya, reproduksi, sosialisasi dan pendidikan, ekonomi, dan pembinaan ligkungan (Saputra, 2020). 
Kampung KB di Jawa Timur berhasil melaksanakan Program Bangga Kencana ditingkat desa. Mata pencaharian masyarakat Desa Sumberkarang mayoritas di sektor pertanian. Pada umumnya, penghasilan di sektor pertanian berpengaruh kecil pada tingkat ekonomi keluarga. Tingkat ekonomi yang rendah juga mempengaruhi kesejahteraan keluarga (Magang, 2019). Pemerintah memprioritaskan wilayah desa terpencil guna meningkatkan taraf hidup masyarakat. Desa Sumberkarang ditunjuk sebagai Kampung KB mewakili Kabupaten Mojokerto pada bulan September 2017. Kondisi masyarakat menjadi pertimbangan dalam pelaksanaan kegiatan Program Kampung KB. Dibentuknya Kampung KB bertujuan meningkatkan kualitas hidup masyarakat di tingkat desa melalui Program Bangga Kencana serta pembangunan lintas sektor untuk mewujudkan keluarga kecil berkualitas (Jurnal Sumatra, 2019).

Desa Sumberkarang merupakan salah satu desa dari 16 desa yang ada di Kecamatan Dlanggu Kabupaten Mojokerto. Berdasarkan data kependudukan Desa Sumberkarang memiliki jumlah penduduk 3.124 jiwa dan jumlah KK 1.004 KK. Adapun jumlah PUS di Desa Sumberkarang sebanyak 773 jiwa, terdiri dari 619 akseptor KB aktif dan 154 non akseptor. Tim penggerak kegiatan Kampung KB yang dilaksanakan di tingkat desa yaitu PPKBD dan sub PPKBD. Desa Sumberkarang menjadi Kampung KB Percontohan karena kegiatan lintas sektor yang dilaksanakan secara aktif. Kolaborasi antar lembaga desa dan peran aktif masyarakat menjadi suatu keunggulan dari Kampung KB Desa Sumberkarang. Adapun Karang Taruna dan PKK juga turut serta dalam pembangunan Desa Sumberkarang.

Suksesnya Desa Sumberkarang dalam pencapaian Program Bangga Kencana tidak lain karena partisipasi masyarakat. Pada dasarnya Pemerintah mencanangkan Program Bangga Kencana guna membangun manusia yang lebih berkualitas (Wulandari, 2008). Partisipasi merupakan keterlibatan fisik maupun pemikiran dalam suatu kegiatan yang didorong atas kesadaran individu. Partisipasi dipengaruhi oleh kondisi sosiologis, ekonomi, politis seseorang dengan latar belakang budaya yang berbeda-beda. Oleh karena itu, partisipasi masyarakat juga dapat berbeda-beda bentuknya (Wulandari, 2008). Kampung KB Desa Sumberkarang mempunyai banyak inovasi meliputi kegiatan Payung Shalawat dan Aplikasi KIA Mobile. Selain itu, kegiatan Lintas Sektor (Linsek) juga dilaksanakan secara aktif. Sejak dicanangkan sebagai Kampung KB. partisipasi masyarakat terus meningkat hingga tahun 2019. Berbeda dengan di masa pandemi, partisipasi masyarakat dalam kegiatan Kampung KB mengalami penurunan. Pandemi Covid-19 menjadi penghambat pelaksanaan kegiatan Kampung KB (Utama, 2020).

Dalam penelitian ini membahas partisipasi masyarakat Desa Sumberkarang dalam pelaksanaan 
Program KB di masa pandemi. Kondisi Kampung KB Desa Sumberkarang tahun 2019 atau sebelum masa pandemi menarik perhatian masyarakat. Hal ini karena Desa Sumberkarang menjadi Juara 1 Lomba Kampung KB se Jawa Timur. Oleh karena itu, Desa Sumberkarang menjadi Kampung KB Percontohan se Jawa Timur. Kampung KB Desa Sumberkarang memiliki keunikan tersendiri di bidang Lintas Sektor. Kegiatan di bidang Lintas Sektor dikelola secara aktif untuk meningkatkan kesadaran masyarakat dalam pembangunan keluarga kecil berkualiltas. Adapun kegiatan di bidang lintas sektor meliputi bidang kesehatan misalnya KB aktif, terbentuknya Pusmupar dan Pospartum. Kegiatan lintas sektor lain adalah Tribina. Kegiatan Tribina terdiri dari Bina Keluarga Balita (BKB), Bina Keluarga Lansia (BKL), Bina Keluarga Remaja (BKR).

Partisipasi masyarakat setelah Desa Sumberkarang dicanangkan sebagai Kampung KB sejak 2017 lalu terus mengalami peningkatan. Meningkatnya kesadaran masyarakat terhadap pentingnya pembangunan keluarga mulai dari kesehatan, perekonomian, dan kesejahteraan keluarga dapat mempermudah pelaksanaan Program Kampung KB. Hal ini menjadi alasan partisipasi masyarakat Desa Sumberkarang sangat aktif dalam program Kampung KB. Berbeda dengan kondisi saat ini, di masa pandemi semua kegiatan masyarakat dibatasi. Kegiatan rutin Program Kampung KB Desa Sumberkarang di masa pandemi antara lain posyandu balita dan posyandu lansia. Beberapa kegiatan di bidang sektor PKB dan Linsek tentang penyuluhan sosialisasi covid-19. Pada bidang kesehatan, kegiatan rutin seperti Posbindu, pelayanan KB MKJP, penyuluhan kesehatan reproduksi tetap berjalan aktif.

Penelitian ini menarik untuk diteliti karena untuk mengetahui bagaimana peran partisipasi masyarakat Desa Sumberkarang dalam program kampung KB di masa pandemi Covid-19 sekarang ini. Melihat pada penelitian terdahulu juga telah membahas tentang persepsi dan partisipasi masyarakat dalam Program Kampung KB di Desa Sumberkarang. Penelitian ini bertujuan untuk mengidentifikasi pelaksanaan Program Kampung KB Desa Sumberkarang di masa pandemi. Adapun tujuan lainnya yaitu mengidentifikasi partisipasi masyarakat dalam Program Kampung KB di masa pandemi. Penelitian ini juga menganalisis proses kegiatan Kampung KB sebelum dan pada saat pandemi. Program Kampung KB merupakan program pembangunan yang berfokus pada pembangunan keluarga. Kegiatan pada Kampung KB dikelola dari, oleh dan untuk masyarakat sendiri. Sasaran yang dituju dalam Program Kampung KB yaitu pembangunan keluarga. Hal ini menunjukkan bahwa Kampung KB dibentuk untuk menerapkan 8 fungsi keluarga sebagai upaya mewujudkan keluarga kecil berkualitas. Adapun 8 fungsi tersebut meliputi fungsi keagamaan, fungsi social budaya, fungsi cinta kasih, fungsi perlindungan, fungsi reproduksi, fungsi social dan pendidikan, fungsi ekonomi dan fungsi lingkungan (Anggraeni, 2020). 
Faktor-faktor terkait dengan kondisi serta potensi wilayah meliputi sumber daya alam ataupun manusia, sarana dan prasarana baik yang menyangkut fisik dan non fisik. Sumber daya manusia menjadi aspek penting dalam pelaksanaan Program Kampung KB. Potensi yang dimiliki sumber daya manusia menjadi salah satu penentu keberhasilan Program Kampung KB. Hal ini karena sumber daya manusia menjadi aspek penting dalam penggerak atau pelaksana program tersebut. Terbentuknya PLKB, PPKBD dan sub PPKBD, Kelompok Kegiatan (POKTAN), serta bidan desa memiliki peranan penting dalam pelaksanaan Program Kampung KB. Kampung KB menjadi wadah untuk pelaksanaan Program Bangga Kencana. Kegiatan Program Bangga Kencana meliputi TRIBINA yaitu Bina Keluarga Balita (BKB), Bina Keluarga Lansia (BKL), dan Bina Keluarga Remaja. Jumlah kelompok kegiatan TRIBINA di Desa Sumberkarang mengalami peningkatan. Pada tahun 2020, jumlah BKB di Desa Sumberkarang sebanyak 5 kelompok, BKL sebanyak 1 kelompok dan BKR sebanyak 1 kelompok. Selain Bina Keluarga Remaja (BKR) di Desa Sumberkarang terdapat 1 kelompok PIK-R. Pusat Informasi dan Konseling Remaja (PIK-R) merupakan suatu wadah yang dikelola dari, oleh, dan untuk remaja. PIK-R berguna untuk memberikan pelayanan informasi dan konseling tentang perencanaan kehidupan berkeluarga bagi remaja (BKKBN, 2020).

Desa Sumberkarang berusaha meningkatkan wawasan serta pengetahuan masyarakat terhadap program-program pemeritah dengan pendampingan yang diperoleh dari Dinas Pengendalian Penduduk, Keluarga Berencana dan Pemberdayaan Perempuan Kabupaten Mojokerto dan PLKB Kecamatan Dlanggu. Pelaksanaan kegiatan Program Bangga Kencana di Desa Sumberkarang mengalami keberhasilan. Hal ini ditunjukkan dengan meningkatnya POKTAN (kelompok kegiatan) BKB, BKL, dan BKR serta PIK-R. Meningkatnya jumlah POKTAN juga didukung dengan adanya kader terlatih (KOMINFO, 2017). Kampung KB Sejahtera Desa Sumberkarang berusaha memaksimalkan pembangunan dan pemberdayaan masyarakat yang fokus terhadap peningkatan kualitas keluarga. Hal ini bertujuan untuk meningkatan ketahanan keluarga melalui Bina Keluarga Balita (BKB), Bina Keluarga Remaja (BKR), Bina Keluarga Lansia (BKL), PIK-R, dan UPPKS dalam rangka mewujudkan keluarga kecil berkualitas. Pelaksanaan kegiatan TRIBINA yaitu penerapan 8 fungsi keluarga, kesehatan reproduksi, serta penyuluhan yang terkait dengan aspek pendidikan dan ekonomi dalam keluarga (BKKBN, 2020).

Penelitian ini berfokus pada partisipasi masyarakat dalam Program Kampung KB di masa pandemi. Partisipasi merupakan pengambilan bagian atau pengikutsertaan. Slamet mengatakan bahwa partisipasi merupakan peran serta seseorang maupun kelompok masyarakat yang aktif dengan proses rumusan 
kebutuhan dan perencanaan hingga tahap pelaksanaan kegiatan melalui pikiran ataupun dalam bentuk fisik (Kaehe, 2019). Partisipasi masyarakat dapat dibedakan menjadi beberapa tingkatan. Menurut Robert Chambers, ada tiga model partisipasi yang digunakan oleh para ahli. Arnstein mengilustrasikan tahapan partisipasi publik (Khotib, 2016) dalam 8 tahapan yaitu sebagai berikut:

1. Manipulation (menipu), ini merupakan tahapan partisipasi yang paling rendah. Pemerintah memilih sebagian dari masyarakat untuk berpartisipasi dengan tugas menampung aspirasi masyarakat.

2. Therapy (pemulihan), pada tahapan ini pemerintah menyampaikan visi misi dan program kerjanya pada wakil masyarakat dan mereka hanya mendengarkan saja.

3. Informing (menginformasikan), pada tahapan ini pemerintah menyampaikan visi misi dan program kerjanya terhadap masyarakat. Hal ini berarti partisipasi masyarakat hanya menunjukkan kehadiran saja dan tidak ada umpan balik atau feedback antara masyarakat dengan pemerintah.

4. Consultation (mengkonsultasikan), pada tahapan ini masyarakat tidak hanya diberkan informasi namun juga ikutserta untuk berbagi pendapat. Terjadi dialog antara masyarakat dengan pemerintah tentang berbagai persoalan, saran dan kritik akan ditampung namun keputusan akhir ada di pemerintah.

5. Placation (mendiamkan), pada tahap ini pemerintah mendengarkan dan menerima kritik ataupun saran yang disampaikan masyarakat, namun pemerintah tetap menjalankan sesuai rencana semula. Pemegang kekuasaan atau pemerintah menunjuk beberapa orang dari bagian masyarakat sebagai anggota suatu badan publik, dimana mereka mempunyai akses untuk menyampaikan aspirasi masyarakat.

6. Partnership (bekerjasama), pada tahap ini masyarakat berhak mengambil keputusan dan bersepakat dengan pemerintah. Masyarakat menjadi partner kerja pemerintah untuk bekerjasama dalam menyusun dan melaksanakan program kerja.

7. Delegated Power (mendelegasikan wewenang), pada tahap ini pemerintah mendelegasikan kewenangan kepada masyarakat dan masyarakat diberi kewenangan untuk mengambil keputusan. Masyarakat mempunyai kekuasaan dan kewenangan membuat keputusan pada rencana tertentu. Pemerintah harus mengadakan negosiasi dengan masyarakat. Hal ini agar masyarakat mempunyai tingkat kendali tanpa adanya tekanan atas keputusan pemerintah.

8. Citizen Control (control publik), masyarakat berpartisipasi dan mengendalikan seluruh proses pengambilan keputusan. Pada tahapan ini masyarakat memiliki kekuatan untuk mengatur program kelembagaan yang terkait dengan kepentingannya. Control masyarakat terhadap 
pemerintah sangat kuat bahkan masyarakat mampu mengevaluasi kinerja pemerintah.

Adapun 8 tahapan partisipasi tersebut menjelaskan bahwa terdapat potensi masyarakat berpartisipasi dalam proses pengambilan keputusan. Menurut Effendi, partisipasi terbagi atas partisipasi vertikal dan partisipasi horizontal (Astuti, 2011), antara lain:

1. Partisipasi vertikal yaitu masyarakat terlibat dalam suatu program, dimana hubungan masyarakat berada sebagai status bawahan, pengikut atau klien.

2. Partisipasi horizontal yaitu setiap anggota masyarakat berupaya untuk berpartisipasi satu dengan yang lainnya. Partisipasi ini merupakan partisipasi diantara sesama warga, dimana masyarakat memiliki kemampuan dalam melaksanakan bersama pada suatu kegiatan pembangunan. Partisipasi semacam ini merupakan tanda masyarakat yang mampu berkembang secara mandiri.

Kolaborasi antar warga masyarakat dapat meningkatkan potensi kesuksesan program pembangunan salah satunya Program Kampung KB. Partisipasi masyarakat dalam pelaksanaan Program Kampung KB sangat penting untuk mencapai tujuan dari program tersebut. Dalam mencapai tujuan tersebut, partisipasi masyarakat tidak hanya sekadar kehadiran yang bersifat pasif. Partisipasi masyarakat harus bersifat aktif dengan melibatkan diri secara utuh dengan mental dan emosinya. Rasa tanggungjawab sebagai salah satu kesadaran diri dan dorongan untuk melakukan sebuah perubahan menjadi kunci kesuksesan dalam program pembangunan.

Adapun penelitian terdahulu yang relevan dengan penelitian ini yaitu penelitian Agus Raikhani membahas tentang kontribusi Program Kampung KB dalam meningkatkan program KKBPK di Kabupaten Jombang. Adanya Program Kampung KB merupakan salah satu langkah pemerintah dalam mewujudkan pembangunan manusia. Beberapa indikator dalam upaya peningkatan Program KKBPK antara lain peningkatan jumlah akseptor KB baru, kesehatan ibu hamil dan menyusui dapat terlayani, remaja aktif dalam kegiatan BKR dan PIK-R, menurunnya angka buta aksara, meningkatnya partisipasi keluarga pra sejahtera dan KS-1 dalam Program UPPKS. Metode yang digunakan yaitu pendekatan deskriptif kualitatif dengan metode eksplorasi pada 3 wilayah Kampung KB yang tersebar di Kabupaten Jombang. Peneliti memilih 3 wilayah Kampung KB yaitu Dusun Pulonasir, Desa Pulosari, Kec. Bareng; Dusun Munggut, Desa Cupak, Kec. Ngusikan; dan Dusun Sumberpelas, Desa Plabuhan, Kec. Plandaan. Wilayah tersebut dipilih karena daerah terpencil, memiliki penduduk pra sejahtera yang cukup tinggi, serta akses pendidikan dan kesehatan yang minim. Hasil penelitian ini yaitu Kampung KB berkontribusi dalam pelaksanaan Program KKBPK. Adapun hambatan yang mengakibatkan kurang maksimalnya kontribusi tersebut yaitu masih kuatnya ego sektoral diantara stakeholder terkait program maupun 
anggaran dana. Oleh sebab itu, perlu adanya political will dan sinergitas antar stakeholder. Kampung KB berkontribusi pada beberapa indikator Program KKBPK seperti peningkatan angka pengguna akseptor baru yang mayoritas terjadi diseluruh lokasi Kampung KB. Selain itu, kesehatan ibu hamil dan menyusui dapat terlayani dengan baik yang ditandai dengan tidak adanya angka kematian terhadap ibu dan bayi di 3 wilayah tersebut. Pelaksanaan program KKBPK juga meningkatkan keaktifan remaja dalam kegiatan BKR dan PIK sehingga menurunnya angka buta aksara. Namun, peningkatan tersebut tidak terjadi pada Program UPPKS. Hal ini karena minimnya pengetahuan untuk menciptakan program serta rendahnya kesadaran maupun partisipasi masyarakat dalam Porgram UPPKS.

Penelitian selanjutnya membahas implementasi Program Kampung KB dalam meningkatkan kualitas hidup masyarakat. Lokasi penelitian ini yaitu di Desa Sumberkarang Kabupaten Mojokerto. Penelitian ini menggunakan pendekatan kualitatif dengan menggunakan sumber data primer dan sekunder. Penelitian ini menggunakan teknik pengumpulan data yaitu observasi, wawancara, dan dokumentasi. Hasil penelitian ini yaitu penerapan SOP Kampung KB di Desa Sumberkarang sudah cukup baik. SOP yang digunakan berupa buku petunjuk teknis pelaksanaan Kampung KB. Petugas Kampung KB cukup banyak dapat mendukung pelaksanaan sosialisasi Program Kampung KB. Pelaksanaan Kampung KB di Desa Sumberkarang juga mendapat dukungan dari tokoh agama, tokoh masyarakat, serta pemerintah desa. Kampung KB di Desa Sumberkarang Sasaran dalam penelitian ini yaitu keluarga, remaja, lansia, PUS. Kampung KB Desa Sumberkarang memenuhi sasaran yang sudah ditargetkan. Faktor pendukung dari implementasi Kampung KB yaitu dukungan dari pemerintah berupa sarana dan prasarana yang memadai. Faktor penghambatnya yaitu kurangnya partisipasi masyarakat.

Penelitian Taat Wulandari membahas persepsi dan partisipasi masyarakat terhadap Program KB. Lokasi penelitian di Desa Panggungharjo Kecamatan Sewon Kabupaten Bantul. Tujuan penelitian ini adalah menganalisis perkembangan Program KB di desa dalam tiga tahun terakhir. Tujuan lainnya yaitu menganalisis partisipasi masyarakat termasuk Kepala Desa, kader dan peserta KB, suami dan kaum muda. Penelitian ini menggunakan metode deskriptif kualitatif. Subjek penelitian ini yaitu Program KB di Desa Panggungharjo Sewon Bantul. Penelitian ini menggunakan teknik pengumpulan data yaitu observasi, wawancara, dan dokumentasi. Teknik analisis yang digunakan yaitu analisis interaktif. Hasil penelitian ini yaitu program KB di Desa Panggungharjo dilaksanakan secara rutin dan sudah menjadi tradisi masyarakat. Program KB mendapat persepsi positif dari masyarakat sehingga partisipasinya cukup tinggi. Dukungan dari tokoh masyarakat, Tim Penggerak PKK, pemerintah desa, serta komitmen dari Kabupaten berpengaruh terhadap tingkat keberhasilan program. Pemerintah desa memberikan fasilitas untuk pelaksanaan penyuluhan yang bersifat masal. Faktor pendorong masyarakat berpartisipasi dalam program $\mathrm{KB}$ yaitu karena program tersebut sudah menjadi tradisi di masyarakat. 
Faktor penghambat Program KB yaitu rendahnya tingkat pemahaman masyarakat. Selain itu, tenaga ahli kesehatan tidak memberikan pelayanan yang lebih responsif terhadap masyarakat.

\section{METODE PENELITIAN}

Penelitian ini menggunakan pendekatan kualitatif. Tujuan penelitian ini yaitu mengidentifikasi partisipasi masyarakat dalam Program Kampung KB Desa Sumberkarang Kecamatan Dlanggu dimasa pandemi. peneliti menggunakan pendekatan kualitatif karena dirasa tepat untuk menjelaskan fenomena yang terjadi di Kampung KB Desa Sumberkarang. Latar belakang Desa Sumberkarang ditunjuk menjadi Kampung KB karena MKJP rendah, CPR rendah, Unmet Need tinggi, KB pria rendah, sarana dan prasarana tidak memadai. Kondisi ini menjadi indikator khusus dibentuknya Kampung KB di Desa Sumberkarang. Sejak dicanangkan sebagai Kampung KB, Desa Sumberkarang banyak mengalami peningkatan. Partisipasi masyarakat terhadap kegitan Program Kampung KB sangat tinggi. Hal ini karena kesadaran masyarakat yang tinggi sehingga pelaksanaan Program Kampung KB dapat maksimal. Desa Sumberkarang menjadi Juara 1 Lomba Kampung KB se Jawa Timur kategori Lintas Sektor tahun 2019. Pada tahun 2020, pelaksanaan kegiatan Kampung KB mengalami hambatan. Hal ini karena tahun 2020 merupakan tahun dimana tersebarnya virus yang mewabah di masyarakat. Pandemi Covid-19 mencipatakan tatanan masyarakat baru. Di masa pandemi kegiatan masyarakat sangat dibatasi. Hal ini karena untuk mencegah penyebaran virus. Pada masa pandemi kegiatan Program Kampung KB juga dibatasi. Penelitian ini membahas mengenai partisipasi masyarakat di masa pandemi. Pendekatan kualitatif pada penelitian ini bertujuan untuk menggambarkan dan mengidentifikasi partisipasi masyarakat dalam Program Kampung KB di masa pandemi. Penyampaian data dari informan dideskripsikan untuk mengetahui bagaimana partisipasi masyarakat di masa pandemi. Penggunaan pendekatan kualitatif dalam penelitian ini didasarkan atas pertimbangan keefektifan dalam mengungkapkan fenomena yang ada. Lokasi penelitian ini yaitu di Kampung KB Desa Sumberkarang Kecamatan Dlanggu Kabupaten Mojokerto. Kampung KB Desa Sumberkarang merupakan Kampung KB Percontohan se Jawa Timur. Desa Sumberkarang meraih Juara 1 Lomba Kampung KB Kategori Lintas Sektor se Jawa Timur tahun 2019. Penelitian ini dilaksanakan pada bulan September hingga bulan Oktober tahun 2020. Penelitian ini menggunakan dua jenis teknik pengumpulan data yaitu data primer dan data sekunder. Data primer adalah data yang diperoleh langsung dari subjek penelitian, kemudian dikumpulkan dan diolah sendiri oleh peneliti. Penelitian ini menggunakan data primer yang diperoleh dengan melakukan observasi terhadap pelaksanaan program Kampung KB di Desa Sumberkarang. Observasi pada dasarnya merupakan kegiatan mengamati menggunakan panca indera untuk memperoleh informasi yang diperlukan. Selain menggunakan teknik 
observasi, peneliti juga menggunakan teknik wawancara mendalam secara informal atau yang disebut in depth interview. In depth interview adalah proses memperoleh informasi untuk tujuan penelitian dengan cara tanya jawab dan bertatap muka antar peneliti dengan informan. Penelitian ini menggunakan pedoman wawancara semi terstruktur. Wawancara ini bertujuan agar peneliti dapat mengembangkan pertanyaan dan pelaksanaannya lebih bebas. Jenis wawancara ini bersifat fleksibel, dimana peneliti dapat mengikuti minat dan pemikiran informan (Rachmawati, 2007). Peneliti menggunakan pedoman semi terstruktur dengan mempersiapkan pertanyaan umum yang kemudian dikembangkan ketika proses wawancara. Pertanyaan yang diajukan peneliti bertujuan untuk menggali isu tertentu dalam penelitian ini. Informan dibebaskan dalam menjawab pertanyaan peneliti, sehingga peneliti dapat memperoleh informasi yang sangat dalam dan rinci.

Teknik analisis data yang digunakan untuk menguraikan pengalaman wanita infertil menggunakan model interaktif Miles dan Huberman. Adapun tahapan model interaktif antara lain: pertama, melakukan reduksi data dengan cara memilah, mengkategorikan, memfokuskan, dan menyusun data dari hasil observasi dan wawancara mendalam yang diperoleh sesuai fokus penelitian. Sebelum reduksi data dilakukan, data hasil wawancara disalin dalam bentuk transkip wawancara dan kemudia diolah dalam bentuk catatan lapangan (field note). Kedua, catatan lapangan yang telah direduksi ditulis dalam bentuk narasi dan menyusun matrik hasil penelitian untuk memudahkan interpretasi teoritik. Ketiga, melakukan interpretasi teoritik berdasarkan kategorisasi data. Keempat, melakukan penarikan kesimpulan.

\section{HASIL PENELITIAN DAN PEMBAHASAN}

Desa Sumberkarang secara geografis terletak di Kecamatan Dlanggu Kabupaten Mojokerto. Luas wilayah Desa Sumberkarang yaitu \pm 149.998 Ha. Batas-batas wilayahnya sebagai berikut: Sebelah Utara: Desa Kedunguneng, Sebelah Selatan: Desa Pohkecik, Sebelah Timur: Desa Ngembeh, Sebelah Barat: Desa Kedunglengkong. Berdasarkan data PLKB Kecamatan Dlanggu tahun 2020, Desa Sumberkarang merupakan daerah dataran sedang (>100-500 mdpl), terdiri dari persawahan dan sungai sehingga penduduknya sebagian besar adalah petani. Secara administratif, Desa Sumberkarang terbagi menjadi 5 Dusun yaitu Sumbersari, Karangnongko, Karangkletak, Ketapang, dan Kertorejo. Data kependudukan Desa Sumberkarang tahun 2019 mencatat sebanyak 3.124 jiwa. Jumlah KK sebanyak 1.004 kepala keluarga dengan kepadatan penduduk $1.382 \mathrm{jiwa} / \mathrm{km}^{2}$. Komposisi penduduk berdasarkan jenis kelamin terdiri dari 1.051 laki-laki dan 1.008 perempuan. Data grafik kependudukan Desa Sumberkarang dari tahun 2017 hingga tahun 2020 mengalami kenaikan. 
Desa Sumberkarang meraih Juara 1 Lomba Kampung KB se Jawa Timur kategori lintas sektor. Kampung KB Desa Sumberkarang menjadi Kampung KB Percontohan se Jawa Timur tahun 2019. Kegiatan Linsek (lintas sektor) yang ada di Desa Sumberkarang yaitu antara lain:

1. Dinas Kesehatan

Adapun kegiatan Linsek dengan Dinas Kesehatan yaitu pendampingan pemeriksaan ibu hamil, pengobatan ringan, POSBINDU, Posyandu Lansia, pelayanan KB MKJP, penyuluhan kesehatan reproduksi, penyuluhan penyakit jiwa, penyuluhan HIV/AIDS.

\section{Dinas Pertanian}

Adapun kegiatan Linsek dengan Dinas Pertanian yaitu sosialisasi kelompok tani, sosialisasi KRPL (Kawasan Rumah Pangan Lestari), pemberian bibit jagung Bissi 226.

\section{Dinas KORAMIL dan POLSEK}

Adapun kegiatannya yaitu bakti sosial, sosialisasi tentang Covid-19, Program RTLH (Rumah Tidak Layak Huni), pelatihan dan pembinaan LINMAS, giat Siskamling, giat rutin dialogis sambang desa, pengawasan pendistribusian Bansos.

\section{Dinas Sosial}

Adapun kegiatan Linsek dengan Dinas Sosial yaitu pembinaan Karang Taruna, Program BPNT (Bantuan Pangan Non Tunai).

\section{KUA}

Adapun kegiatan Linsek dengan KUA yaitu giat keagamaan, Pendewasaan Usia Perkawinan (PUP), penyuluhan untuk calon pengantin, pemberian santunan zakat.

Aktifnya kegiatan Linsek di Kampung KB Desa Sumberkarang menjadi keunggulan dan keunikan tersendiri. Hal ini karena tidak semua Kampung KB aktif dalam kegiatan Linsek. Selain kegiatan Linsek, Kampung KB Desa Sumberkarang juga memiliki inovasi yang bermanfaat bagi masyarakat. Inovasi Kampung KB Desa Sumberkarang yaitu Payung Shalawat dan Aplikasi KIA Mobile. Payung Shalawat merupakan Majelis Ta'lim dan Dzikir yang dilaksanakan setiap Jumat Legi. Kegiatan Keagamaan ini dilaksanakan dengan konsep pengajian umum. Payung Shalawat merupakan salah satu identitas bagi masyarakat Desa Sumberkarang. Kegiatan ini sebagai penerapan 8 Fungsi Keluarga yaitu Fungsi Agama dan Sosial Budaya. Adanya kegiatan keagamaan ini memberi pengaruh positif bagi masyarakat karena meningkatkan ketaqwaan warga masyarakat, memupuk kerukunan umat beragama, 
dan melestarikan bentuk seni dan budaya masyarakat. Sedangkan, Aplikasi KIA Mobile merupakan aplikasi via andorid yang dirancang oleh SMKN Dlanggu sebagai langkah perencanaan kesehatan ibu dan anak, serta memberikan manfaat bagi WUS dalam mengetahui masa subur, perkembangan kehamilan, penggunaan kontrasepsi yang tepat, dan PHBS.

Inovasi yang ciptakan oleh Kampung KB Desa Sumberkarang menjadi keunggulan pada Kampung KB ini. Kampung KB Desa Sumberkarang menjadi Kampung KB Percontohan yang menginspirasi. Kampung KB Sejahtera telah menunjukkan kemajuan pesat dalam pemecahan masalah kependudukan dan kesehatan masyarakat. Sebelum dicanangkan sebagai Kampung KB, Desa Sumberkarang menghadapi problem antara lain: rendahnya KB MKJP, CPR rendah, Unmet Need tinggi, rendahnya KB pria, sarana dan prasarana tidak memadai. Hal ini yang menjadi problem Desa Sumberkarang sebelum dicanangkan sebagai Kampung KB. Setelah dicanangkan sebagai Kampung KB tahun 2017 lalu, Desa Sumberkarang mampu menyelesaikan permasalahan dan meningkatkan kualitas masyarakat khususnya permasalahan kesehatan. Meningkatnya kesadaran ber-KB di masyarakat Desa Sumberkarang menjadi suatu prestasi yang perlu diapresiasi. Kampung KB Desa Sumberkarang berhasil meningkatkan akseptor KB setiap tahunnya.

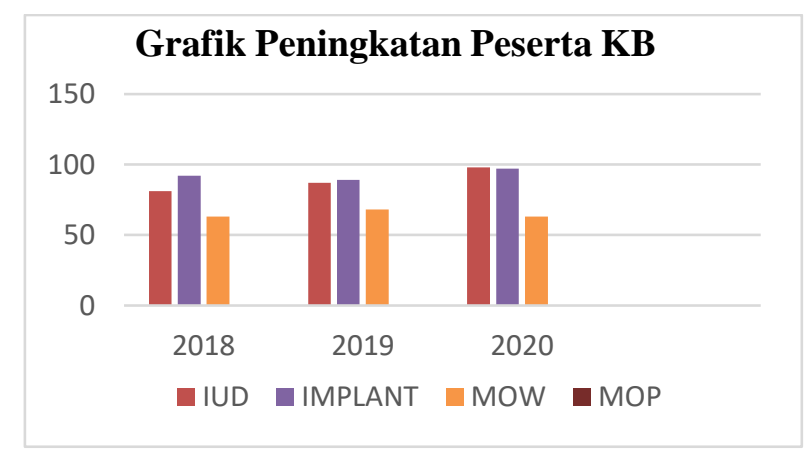

Sumber: PLKB Kecamatan Dlanggu

Berdasarkan data PLKB Kecamatan Dlanggu, akseptor KB Non MKJP tahun 2018 berjumlah 242 akseptor, tahun 2019 berjumlah 347 akseptor, dan tahun 2020 berjumlah 361 akseptor. Akseptor KB MKJP tahun 2018 berjumlah 236 akseptor, tahun 2019 berjumlah 244 akseptor, dan tahun 2020 berjumlah 258 akseptor. Pencapaian yang diraih Desa Sumberkarang di masa pandemi yaitu meningkatnya akseptor KB MKJP. Berdasarkan data di atas, akseptor KB MKJP mengalami peningkatan signifikan pada tahun 2020. Akseptor KB Non MKJP di Desa Sumberkarang tahun 2020 berjumlah 361 akseptor meliputi Suntik 275 (25,52\%), Pil 83 (13,4\%), Kondom 3 (0,48\%). Di samping itu, akseptor KB MKJP berjumlah 258 akseptor meliputi IUD sebanyak 98 (15,83\%), MOW sebanyak 63 (10,17\%), MOP sebanyak 0 (0\%), Implant 97 (14,86\%). 
Peningkatan akseptor KB tidak lepas dari peran PLKB Kecamatan Dlanggu. Pemantauan dan evaluasi kegiatan dilaksanakan agar dapat meningkatkan kualitas pelaksanaan program. Kegiatan pada Program Kampung KB di masa pandemi mengalami kendala. Beberapa kegiatan dihentikan karena untuk mencegah penyebaran Virus Corona. Penyebaran Covid-19 di Indonesia sejak Maret 2020 lalu memaksa seluruh masyarakat harus membiasakan diri dengan norma baru. Seperti halnya proses pelaksanaan kegiatan di Kampung KB sangat dibatasi dan menerapkan protokol kesehatan. Himbauan untuk tidak keluar rumah dan larangan berkerumun mengakibatkan beberapa kegiatan dihentikan. Selain itu, larangan untuk mengadakan kegiatan yang melibatkan banyak orang juga menghambat pelaksanaan kegiatan yang telah dijadwalkan. Pelaksanaan kegiatan Kampung KB saat ini dilakukan dengan menerapkan protokol kesehatan. PLKB beserta PPKBD dan sub PPKBD berupaya untuk mensosialisasikan kepada masyarakat tentang PHBS dan penerapan protokol kesehatan dalam pelaksaan kegiatan. Kegiatan di Kampung KB Desa Sumberkarang yang sebelumnya dihentikan saat ini mulai diaktifkan kembali. Adapun kegiatan yang dilaksanakan di masa pandemi, yaitu Posyandu Balita, Posyandu Lansia, BKB, BKL dan BKR. Kegiatan tersebut tetap diadakan saat pandemi namun partisipasi masyarakat berkurang. Hal ini karena masyarakat memiliki kekhawatiran terhadap penyebaran Virus Corona. Kegiatan Posyandu Balita dan BKB dilaksanakan dengan menerapkan protokol kesehatan.

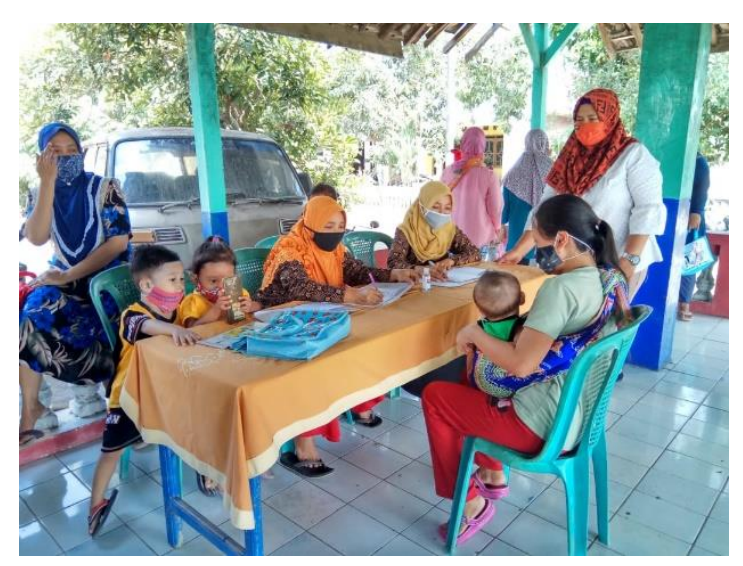

Sumber: Dokumentasi Penulis

Teknis pelaksanaan kegiatan Posyandu Balita dan BKB dimasa pandemi berbeda dengan sebelumnya. Ibu dan balita yang menghadiri kegiatan ini melakukan pemeriksaan kesehatan balita secara bergilir. Pemeriksaan kesehatan dilaksanakan dengan waktu yang terbatas untuk menghindari adanya kerumunan. Sebelum pandemi kegiatan Posyandu Balita dan BKB tidak hanya pemeriksaan kesehatan balita melainkan juga diadakan sosialisasi yang dihadiri ibu-ibu. Sosialisasi ini diadakan 
untuk meningkatkan pengetahuan ibu terhadap kebutuhan balita seperti makanan sehat dan pemantauan tumbuh kembang balita.

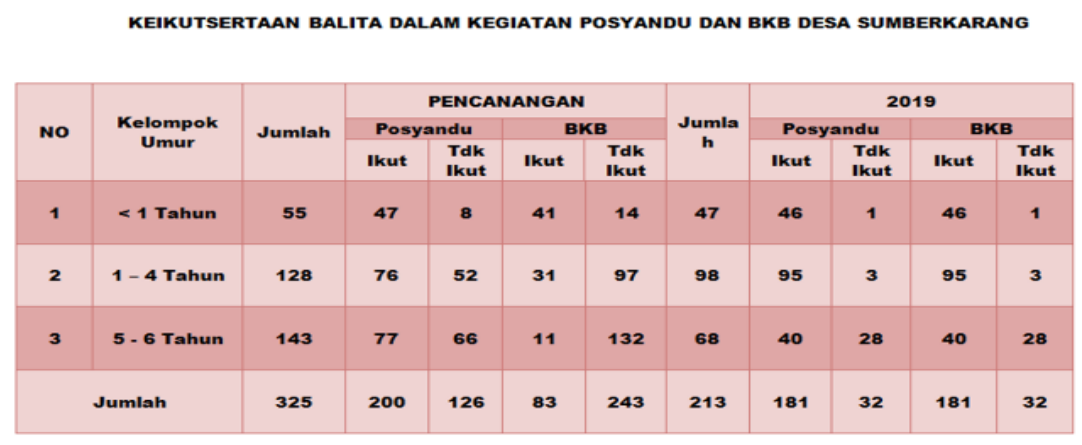

Sumber: PLKB Kecamatan Dlanggu

Berdasarkan data di atas, jumlah partisipasi keluarga yang memiliki balita tahun 2017 hingga 2019 dalam kegiatan Posyandu terus meningkat. Hal ini dilihat dari data balita yang tidak ikut dalam Kegiatan Posyandu setiap tahunnya berkurang. Data tersebut menunjukkan adanya peningkatan kesadaran masyarakat terhadap kesehatan balita. Peningkatan kesadaran masyarakat dapat mengurangi resiko stunting pada anak. Pelaksanaan kegiatan Posyandu Balita dan BKB di Desa Sumberkarang sangat aktif. Berdasarkan data PLKB Kecamatan Dlanggu, jumlah POKTAN BKB saat pencanangan hingga tahun 2020 meningkat. Jumlah POKTAN saat pencangan tahun 2017 hanya 1 kelompok. Pada tahun 2020, jumlah POKTAN meningkat sebanyak 5 kelompok.

Kegiatan lainnya yaitu Posyandu Lansia dan BKL. Saat pandemi, kegiatan Posyandu Lansia ditiadakan. Hal ini karena daya tahan tubuh lansia yang lemah sehingga mudah terserang Virus Corona. Layanan pemeriksaan kesehatan lansia tetap ada namun dilaksanakan di Puskesmas. Di masa pandemi, pusat pelayanan kesehatan lansia berada di Puskesmas. Selain Posyandu Lansia, kegiatan rutin lainnya yaitu senam lansia. Di masa pandemi kegiatan senam lansia ditiadakan. Hal ini karena kegiatan senam lansia sangat beresiko penyebaran Virus Corona. Partisipasi lansia dalam Posyandu Lansia dan BKL sebelum pandemi sangat tinggi.

\section{KESIMPULAN}

Desa Sumberkarang menjadi Kampung KB Percontohan se Jawa Timur tahun 2019. Partisipasi masyarakat dalam kegiatan Program Kampung sangat tinggi. Pada saat pandemi Covid-19, partisipasi masyarakat menurun. Hal ini karena kekhawatiran masyarakat terhadap penyebaran Covid-19. Kegiatan Program Kampung KB Desa Sumberkarang saat pandemi dibatasi. Teknis pelaksanaan kegiatan di 
masa pandemi berbeda dari biasanya. Kegiatan dilaksanakan dengan menerapkan protokol kesehatan dan PHBS. Seperti halnya pelaksanaan Posyandu Balita, pemeriksaan kesehatan balita dilakukan secara bergilir. Selain itu, kegiatan penyuluhan juga ditiadakan. Hal ini untuk menghindari kerumunan sebagai upaya mencegah penyebaran Covid-19.

\section{DAFTAR PUSTAKA}

Anggraeni, N. (2020). Implementasi Program Kampung Keluarga Berencana Dalam Meningkatkan Kualitas Hidup Masyarakat (Studi Kasus Desa Sumberkarang Kabupaten Mojokerto). Jurnal Respon Publik, 14(1), 32-41.

Astuti, S. (2011). Konsep Dasar dan Teori Partisipasi. Retrieved from https://eprints.uny.ac.id/7876/3/bab 2 - 08110244006.pdf

BKKBN. (2018). Delapan Fungsi Keluarga. Retrieved October 2, 2020, from BKKBN website: https://kampungkb.bkkbn.go.id/postSlider/3867/26322

BKKBN. (2020). Profil Kampung KB "Sejahtera" Sumberkarang. Retrieved October 5, 2020, from BKKBN website: https://kampungkb.bkkbn.go.id/profile/3432

BPS, J. (2020). Jumlah Penduduk Provinsi Jawa Timur, 2016-2020. Retrieved September 23, 2020, from jatim.bps.go.id website: https://jatim.bps.go.id/quickMap.html

Jurnal Sumatra. (2019). Desa Sumberkarang Wakili Mojokerto Ikut Lomba Kampung KB. Retrieved October 1, 2020, from jurnalsumatra.com website: https://jurnalsumatra.com/desa-sumberkarang-wakili-mojokerto-ikut-lomba-kampung$\mathrm{kb} /$

Kaehe, D. (2019). Partisipasi Masyarakat dalam Perencanaan Pembangunan Di Kampung Pintareng Kecamatan Tabukan Selatan Tenggara. Retrieved from file:///C:/Users/HP/Downloads/25447-52086-1-SM.pdf

Kanalsatu.com. (2019). Kampung KB Jadi Wahana Pemberdayaan Masyarakat. Retrieved September 29, 2020, from Kanalsatu.com website: http://kanalsatu.com/id/post/53386/kampung-kb-jadi-wahana-pemberdayaanmasyarakat-

Khotib, A. (2016). Partisipasi Publik Arnstein. Retrieved September 4, 2020, from Kompasiana https://www.kompasiana.com/ahmadkhotib/57f93f984c7a619e2cb96ea7/partisipasipublik-ala-arnstein?page=all\#: :text=Arnstein mengilustrasikan tahapan partisipasi public, \%2C Delegated Power\%2C Citizen Control

KOMINFO. (2017). Kampung KB: Inovasi Strategis Memberdayakan Masyarakat. Retrieved from https://kominfo.go.id/index.php/content/detail/9841/kampung-kb-inovasistrategis-memberdayakan-masyarakat/0/artikel_gpr

Magang. (2019). Ini Tujuan Dibentuknya Kampung KB. Retrieved October 6, 2020, from Borneonews.co.id website: https://www.borneonews.co.id/berita/126001-ini-tujuandibentuknya-kampung-kb

Rachmawati, I. (2007). Pengumpulan Data dalam Penelitian Kualitatif: Wawancara. Jurnal Keperawatan Indonesia, 11(1), 36-40. Retrieved from https://media.neliti.com/media/publications/105145-ID-pengumpulan-data-dalampenelitian-kualit.pdf

radarbangsa. (2019). Desa Sumberkarang Terpilih Mewakili Kab Mojokerto dalam Lomba Kampung KB Tingkat Prop Jatim. Retrieved October 6, 2020, from radarbangsa website: https://radarbangsa.co.id/desa-sumberkarang-terpilih-mewakili-kab-mojokerto-dalamlomba-kampung-kb-tingkat-prop-jatim/

Rahman, M. (2019). Peran Bkkbn Dalam Mengatur Kependudukan Indonesia Melalui. 
Retrieved from https://www.researchgate.net/publication/336698824_PERAN_BKKBN_DALAM_ME NGATUR_KEPENDUDUKAN_INDONESIA_MELALUI_PR̄OGRAM_KELUARGA BERENCANA/link/5dada8c992851c577eb9547a/download

Saputra, A. (2020). 8 Fungsi Keluarga, Modal Mencapai Kesejahteraan Keluarga. Retrieved October 5, 2020, from Perwakilan BKKBN Provinsi Kalimantan Tengah website: http://kalteng.bkkbn.go.id/?p=674

Utama, A. (2020). Dampak Pandemi Covid-19 Bagi Program KB di Indonesia. Retrieved October 6, 2020, from Voaindonesia.com website: https://www.voaindonesia.com/a/dampak-pandemi-covid-19-bagi-program-kb-diindonesia/5411570.html

Welianto, A. (2020). KB, Salah Satu Usaha Pemerintah Untuk Menekan Tingkat Pertumbuhan Penduduk. Retrieved September 30, 2020, from Kompas.com website: https://www.kompas.com/skola/read/2020/08/11/141500569/kb-salah-satu-usahapemerintah-untuk-menekan-tingkat-pertumbuhan-penduduk?page=all

Wulandari, T. (2008). Persepsi dan Partisipasi Masyarakat Terhadap Program Keluarga Berencana (Penelitian di Desa Panggungharjo, Kec. Sewon, Kab. Bantul). DIMENSIA, 2(1). https://journal.uny.ac.id/index.php/dimensia/article/viewFile/3399/2884 